\title{
DIETARY INTAKE OF ANTIOXIDANT VITAMINS IN DIETS OF AMATEUR ADULTS PREPAPING FOR A MARATHON
}

\author{
Aureliusz Kosendiak, 1 , A, D, E Anna Kawicka, ${ }^{2, B, C, D}$ Dorota Różańska, ,, B, D

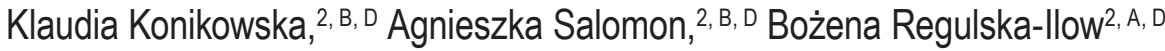 \\ ${ }^{1}$ Department of Organisation and Management, Wroclaw Medical University, Wrocław \\ 2 Department of Dietetics, Wroclaw Medical University, Wrocław

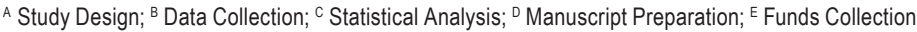 \\ Address for correspondence: \\ Anna Kawicka \\ Wroclaw Medical University, Department of Dietetics \\ Parkowa 34, 51-616 Wrocław, Poland \\ E-mail: anna.kawicka@umed.wroc.pl
}

\begin{abstract}
Ahstract. The aim of this study was to evaluate the content of antioxidant vitamins in the diet of amateurs preparing for a marathon. The study group consisted of 92 women ( $30.8 \pm 6.7$ years old) and 66 men ( $33.2 \pm 6.6$ years old). Assessment of the content of antioxidant vitamins in the diet of the subjects was made on the basis of the 3-day dietary records. The average content of vitamin $A$ in the diets of women surveyed was $1,296.8 \mathrm{mg} /$ day and $1,499.7 \mathrm{mg} /$ day in the diets of men. The vitamin A content of less than $90 \%$ of the norm was observed in the diets of $2.2 \%$ women and $9.1 \%$ men. The average content of vitamin $\mathrm{C}$ in the diet amounted to 130.6 (women) and 111.4 (men) $\mathrm{mg} /$ day. Significantly more men than women $(30 \%$ vs $13 \%$ ) did not fulfill the norm for vitamin $\mathrm{C}$. The average vitamin $\mathrm{E}$ content was higher in the diets of men than in women (15.2 vs $13.0 \mathrm{mg} / \mathrm{day} ; \mathrm{p}<0.0001)$. The vitamin $\mathrm{E}$ content was insufficient compared to norms in the diets of $10 \%$ of women and $12 \%$ of men. The average content of vitamins A, C and $E$ in the diet of the subjects significantly exceeded the recommendations. The largest proportion of diets, not meeting the stated norms for vitamin $\mathrm{C}$ were in the group of men.
\end{abstract}

Key WOrlls: antioxidant vitamins, marathon, 3-day dietary records

\section{Introduction}

One of the factors contributing to the occurrence of oxidative stress is increased physical activity. The formation of reactive oxygen species (ROS) in the body is a natural process that occurs as a result of aerobic respiration, but their production is significantly greater during physical activity. Athletes consuming a high energy diet, compared to those with low and moderate physical activity, provide the body more nutrients that are substrates of metabolism, for which free radicals are byproducts (Radak et al. 2001; Sachdev and Davies 2008).

ROS in small quantities are signaling molecules in the course of many life processes. However, the disturbance of homeostasis in the body, i.e. their overproduction, beyond the capacities of the cells to neutralize them, leads 
to accumulation of large amounts of these molecules, referred to as oxidative stress. This condition, as well as insufficient antioxidant defense of cells, may lead to a number of defects in tissues and cells (Valko et al. 2007; Czajka 2006).

Protective mechanisms against oxidative stress of cells are formed at three levels. In the first level, antioxidant enzymes such as superoxide dismutase, catalase and glutathione peroxidase take part. The second line of defense are the non-enzymatic antioxidants such as glutathione and food derived antioxidant vitamins and flavonoids. Antioxidants that are ingested with the diet are therefore, an important support for the enzymatic antioxidant defense mechanisms. In the last stage of the antioxidant defense of the body, repair proteins, which rebuild modified or damaged DNA molecules and others, are involved (Chajka 2006; Grajek 2007).

During prolonged endurance exercises, there is an overproduction of free radicals, which contributes to a number of changes in the tissues, organs and cells. With the failure of endogenous antioxidant defense systems and comorbid insufficient supply of exogenous antioxidants results in the worsening of oxidative stress (Radak et al. 2001; Sachdev and Davies 2008; Bloomer et al. 2006). To restore homeostasis, the organism should be neutralized by food ingredients, with antioxidant and anti-free radicals properties, such as vitamins $A, C, E$, and bioflavonoids (Sen 2001; Morillas-Ruiz et al. 2006).

It is therefore important to monitor the composition of the diet of people who undertake prolonged exertion e.g. preparing for a marathon race, in terms of the supply of the substances of an antioxidant nature to help mitigate the effects of oxidative stress.

The aim of this study was to evaluate the content of antioxidant vitamins in the diet of adults - amateurs, preparing for a marathon.

\section{Material and methods}

The study group consisted of 158 people, 92 women and 66 men who took part in the "I Ty możesz zostać maratończykiem" program in 2012 and 2013. The average age of women was $30.8 \pm 6.7$ years, and $33.2 \pm 6.6$ years for men. Abnormal BMl (body mass index) was found in $18 \%$ of women and $45 \%$ men. The characteristics of the study group are shown in Table 1.

Tahle 1. Anthropometric characteristics of the surveyed women and men preparing for a marathon

\begin{tabular}{llcccc}
\hline \multirow{2}{*}{$\begin{array}{c}\text { Analyzed } \\
\text { paramaters }\end{array}$} & \multirow{2}{*}{$\mathrm{U}$} & \multicolumn{2}{c}{ Women $(\mathrm{n}=92)$} & \multicolumn{2}{c}{ Men $(\mathrm{n}=66)$} \\
\cline { 2 - 6 } & & $\mathrm{X} \pm \mathrm{SD}$ & $\mathrm{Me}$ & $\mathrm{X} \pm \mathrm{SD}$ & $\mathrm{Me}$ \\
\hline Age & years & $30.8 \pm 6.7$ & 30.0 & $33.2 \pm 6.6$ & 32.5 \\
Height & $\mathrm{cm}$ & $166.0 \pm 6.1$ & 165.0 & $178.9 \pm 7.1$ & 179.0 \\
Body weight & $\mathrm{kg}$ & $61.8 \pm 9.1$ & 60.8 & $81.2 \pm 11.9$ & 79.2 \\
BMl & $\mathrm{kg} / \mathrm{m}^{2}$ & $22.4 \pm 2.7$ & 21.7 & $25.3 \pm 2.8$ & 24.9 \\
\hline
\end{tabular}

n- number of people studied; X-arithmetic average; SD - standard deviation; Me - median; U- unit; BMI- body mass index.

The program "I Ty możesz zostać maratończykiem" began at the end of March and was aimed at preparing amateur runners to compete in the Wroclaw marathon, which takes place every year in mid-September. The program was implemented in the form of endurance training. During the program, volunteers participated in organized training units twice a week. They were also supposed to perform additional units in their own free time. 
Assessment of the content of antioxidant vitamins in the diet of the subjects was made on the basis of the current 3-day dietary records. Participants received detailed, written instructions on how to record intake of products, food and beverages during a 3-day period, including: 1 training day, 1 day without training and a special day (weekend). Dietary interviews were collected in May and June. The composition of the food recorded using households measures was then verified by trained interviewers using the "Album of photographs of products and dishes" (Szponar et al. 2008) by assigning appropriate weight to all products. Nutritional analysis of collected interviews was carried out using a computer program, "The Food Processor SQL" containing the Polish database by Kunachowicz et al. (2005).

The average content of antioxidant vitamins in the 3-day daily food rations was calculated for each person, and then compared with the norms (Jarosz 2012) using two parameters: the average fulfillment of norms and percentage of people who have vitamin contents in their diets below the norms. The content of vitamins $A$ and $C$ were compared with the norms at the level of the EAR (Estimated Average Requirement), and vitamin $E$ with the norm at the level of $\mathrm{Al}$ (Adequate Intake), assuming the values specified in the amendment of nutrition norms for the Polish population, for the appropriate gender and age (Jarosz 2012). In addition, the percentage of respondents fulfilling the standard dietary requirements for antioxidant vitamins were rated in the following ranges: $<90 \%, 90$ $110 \%, 111-150 \%, 151-200 \%$, >200\%.

\section{Statistical analysis}

Comparison of vitamins in the diets of women and men was performed using a non-parametric $U$ MannWhitney test, and categorical variables using a $\mathrm{Chi}^{2}$ test. Statistical analysis of the results was carried out using a computer program STATISTICA PL v.10, by StatSoft Inc. (USA).

\section{Results}

The daily food rations (DFR) were evaluated in terms of the content of antioxidant vitamins A, E and C (Table 2).

Table 2. The mean content of antioxidant vitamins in the diets of the surveyed women and men preparing for a marathon

\begin{tabular}{lccccccc}
\hline & & \multicolumn{3}{c}{ Women $(\mathrm{W}) \mathrm{n}=92$} \\
\cline { 3 - 8 } \multicolumn{1}{c}{ Vitamins } & $\mathrm{U}$ & $\mathrm{X} \pm \mathrm{SD}$ & $\mathrm{Me}$ & $\begin{array}{c}\text { \% fulfillment of standards } \\
(\mathrm{X} \pm \mathrm{SD})\end{array}$ & $\mathrm{X} \pm \mathrm{SD}$ & $\mathrm{Me}$ & $\begin{array}{c}\text { \% fulfillment of standards } \\
(\mathrm{X} \pm \mathrm{SD})\end{array}$ \\
\hline $\mathrm{A}^{*}$ & $\mathrm{\mu g}$ & $1296.8 \pm 911.6$ & 1139.8 & $259.4 \pm 182.3$ & $1499.7 \pm 1465.4$ & 1194.2 & $238.0 \pm 232.6$ \\
Retinol & $\mu \mathrm{g}$ & $492.1 \pm 700.4$ & 345.8 & - & $832.7 \pm 1224.7$ & 538.6 & - \\
$\beta$-carotene & $\mu \mathrm{g}$ & $4812.9 \pm 3376.0$ & 3673.1 & - & $3983.9 \pm 2591.5$ & 3252.2 & - \\
$\mathrm{C}^{*}$ & $\mathrm{mg}$ & $130.6 \pm 76.2$ & 115.4 & $217.7 \pm 127.0$ & $111.4 \pm 66.5$ & 101.2 & $148.6 \pm 88.7$ \\
$\mathrm{E}^{* *}$ & $\mathrm{mg}$ & $13.0 \pm 5.6$ & 11.9 & $163.0 \pm 70.2$ & $15.2 \pm 5.4 \mathrm{a}$ & 15.0 & $151.6 \pm 54.0$ \\
\hline
\end{tabular}

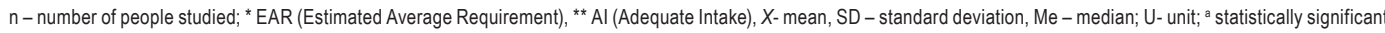
difference $W$ vs $M p<0,05$.

Average daily vitamin A content, expressed as retinol equivalent, in the diets of women surveyed was $1,296.8 \mathrm{mg}$, of which $62 \%$ came from $\beta$-carotene, and $38 \%$ of retinol. The average daily content of vitamin $A$ in the diets of men was $1,499.7 \mathrm{mg}$, of which $44 \%$ came from $\beta$-carotene, and $56 \%$ of retinol. An insufficient content of vitamin A, compared to the EAR was recorded in the diets of $2.2 \%$ of women and $9.1 \%$ of men (Figure 1). DFR 
of the surveyed women fulfilled the norm for vitamin A on average by $259.4 \%$, and the DFR for the men surveyed by $238.0 \%$. The intake of vitamin A in the diets of approximately $60 \%$ of women's and $46 \%$ of men's was higher by $200 \%$ of the norm.

a) vitamin $A$ intake WOMEN

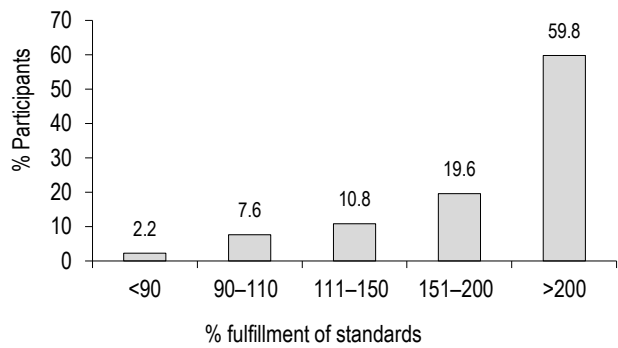

b) vitamin $A$ intake MEN

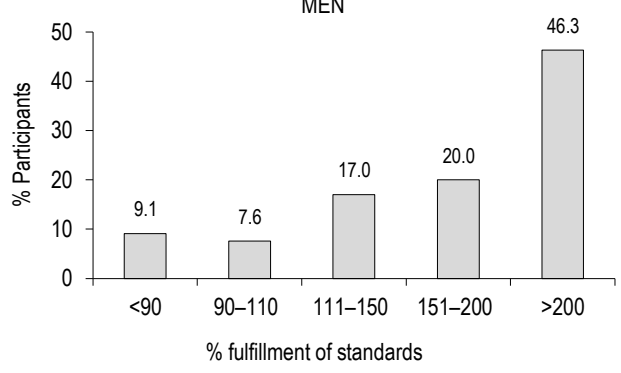

Figure 1. Distribution of dietary daily intake of vitamin A in the study group: a) women, b) men

Average daily vitamin C content in the DFR of surveyed women and men amounted to $130.6 \mathrm{mg}$ and $111.4 \mathrm{mg}$, respectively (Table 2). Although the energy value of diets was significantly higher for men than for women $(2,808.1$ \pm 731.6 vs $1,982.3 \pm 506.5 \mathrm{kcal} ; \mathrm{p}<0.05$ ) significantly more men's than women's diet did not fulfill the norm for vitamin C. Diets of $13 \%$ of women and $30 \%$ of men did not provide sufficient amounts of vitamin C. In the diets of approximately $46 \%$ of women and $17 \%$ of men, intake of vitamin C exceeded the norm two-fold (Figure 2). DFR of the surveyed women fulfilled the norm for vitamin C on average by $217.7 \%$, and the diet of men by $148.6 \%$ (Table 2).

a) vitamin $C$ intake WOMEN

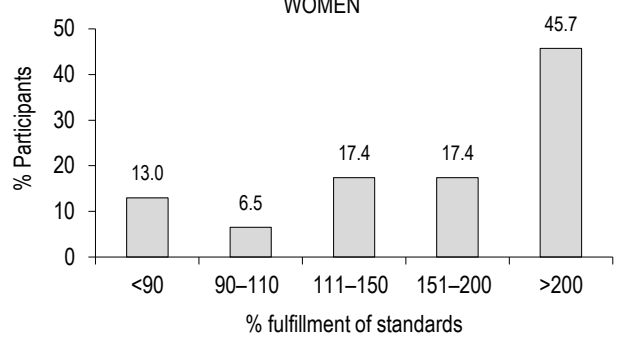

b) vitamin $\mathrm{C}$ intake MEN

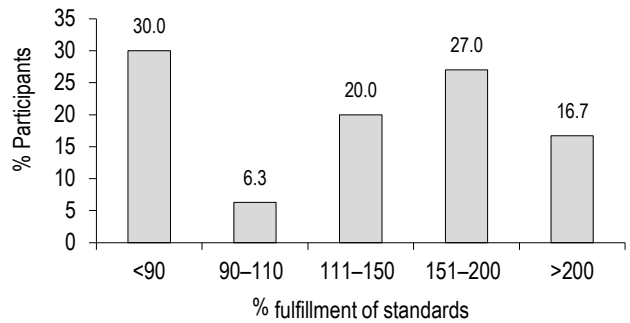

Figure 2. Distribution of dietary daily intake of vitamin C in the study group: a) women, b) men

The average content of vitamin $E$ was significantly higher in the diets of men than women ( $15.2 \mathrm{vs} 13.0 \mathrm{mg} / \mathrm{day}$; $p<0.0001$ ) (Table 2). Insufficient levels of vitamin E compared to the level of Al were reported in the diets of $10 \%$ of women and $12 \%$ of men. In addition, it was found that the diets of $25 \%$ of women and $21 \%$ of men vitamin $E$ 
content exceeded $200 \%$ of the norm (Figure 3). DFR of surveyed women fulfilled the norm for vitamin $E$ on average by $163 \%$, and the diet of men by $151.6 \%$ (Table 2 ).
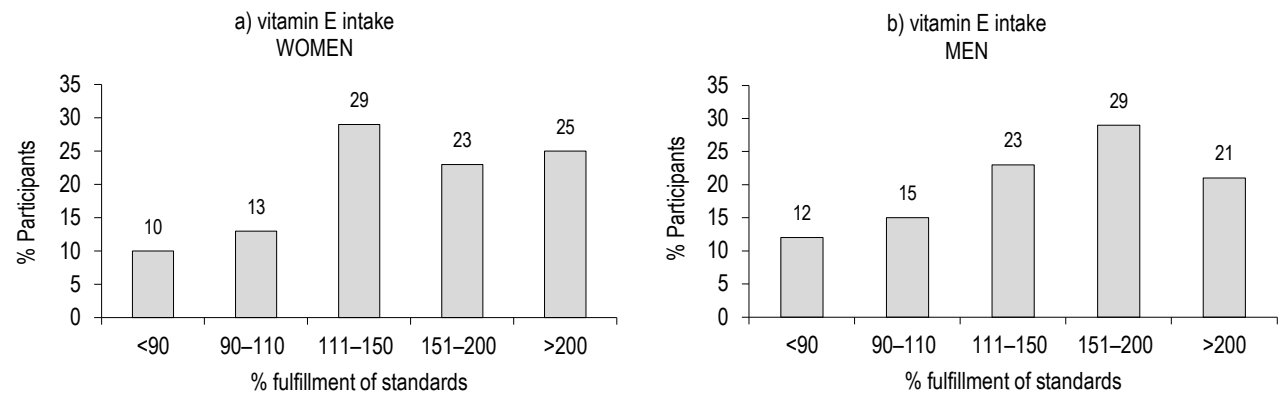

Figule 3. Distribution of dietary daily intake of vitamin $\mathrm{E}$ in the study group: a) women, b) men

\section{Discussion}

The basic task that an athlete's diet must fulfil is optimal supply of energy needs and building blocks of the body. At the same time, the dietary needs should encourage the development of functional capacity and counter the effects of training overload.

During increased physical activity, not only is the supply of energy to the needs of the body important, but also building and regulating nutrients. Physical activity increases the intensity of metabolic processes. There are many by-products of metabolism, and an excessive amount of free radicals, which can have a negative effect on the body and hinder regeneration. It is therefore necessary to provide the body, together with the diet, adequate amounts of dietary antioxidant vitamins to restore the homeostasis of the organism.

In addition to the deficit of glycogen and the presence of lactic acid, one of the factors causing exerciseinduced muscle fatigue, is the production of free radicals in the active skeletal muscles. A key role in protecting against oxidative damage of muscles caused by exercise, is played by antioxidants from food. An increased dietary intake of antioxidant vitamins has been observed both in our study and among other Polish athletes (Zapolska et al. 2014), and among volleyball players from Greece (Papadopoulou et al. 2002). Extra vitamin supplements can be helpful in improving the overall efficiency of the body, because they prevent the lowering of blood antioxidant capacity and reduce the activity of ROS. However, it should be noted that, under certain conditions, too high dose of some antioxidants, administered in the form of supplements can operate pro-oxidant. The best sources of antioxidants are natural foods, especially fruits and vegetables, tea, chocolate, the consumption of which does not put one in danger of an overdose.

Insufficient intake of vitamin E leads to increased oxidative stress, neurodegenerative changes, hemolysis, and muscle wasting (Lukaski 2004). Vitamin E is a strong antioxidant and a-tocopherol is a component of all biological membranes in the body and thus prevents oxidation of fatty acids in cell membranes (Biesalski and Grimm 2012). This prevents oxidative cell damage which may be severe during prolonged physical exertion. 
In addition, vitamin E promotes the transformation of slow-twitch fiber (type I) into the fast-twitch (type II), which may impair the capacity of the organism (Lukaski 2004). These changes will be particularly disadvantageous for people undertaking prolonged exertion, i.e. endurance activities such as marathon. Muscles, which consist mainly of fasttwitch fibers contain more glycogen as well as enzymes involved in the release of energy in anaerobic conditions, yet also contain little myoglobin are called white. This type of muscle on one hand shrinks faster and stronger, but also quickly loses energy reserves and gets tired. By contrast, muscles containing slow-twitch fiber (called red, because they contain large amounts of myoglobin) are adapted to long-term physical exertion (Nazar 2013). Types I and II muscle fiber have different oxidative metabolism. Type I fibers may use larger amounts of vitamin $E$ than type II fibers (Lukaski 2004). Vitamin E causes the increase in the activity of circulating creatine kinase, which may indicate an increase in skeletal muscle repair (Evans 2000).

Nutritional deficiencies of vitamin $\mathrm{E}$ are higher in physically inactive people than in athletes (Wierniuk and Włodarek 2013). In our study, insufficient content of vitamin $E$ in the diet was found on average in every 10th woman and every 8th man. In a study conducted by Wierniuk and Włodarek (2013) too low vitamin E content was observed in the diets of $40 \%$ of men who carry out aerobic sports. In contrast Gogojewicz et al. (2012) estimated that the average content of vitamin $\mathrm{E}$ in the diet of women involved in fitness was an average of $4.1 \mathrm{mg} / \mathrm{day}$ and was lower than the values obtained in our study and in studies of other authors (Pilis et al. 2014; Gacek 2010). The vitamin E content in the diets of about $80 \%$ of the people surveyed in our study exceeded the norm. Similar results were obtained in a group of athletes involved in football (Lange et al. 2007), whereas there was a deficiency in the DFR of football players during the match season (Chalcarz et al. 2008).

The role of vitamin $\mathrm{C}$ in the body is mainly related to its antioxidant activity, but it takes part in a number of different processes, which may affect the physical fitness of the organism. Vitamin $C$ is involved, among other things, in the synthesis of carnitine in the muscles, which is required for handling and transport of fatty acids into the mitochondria where they are used for energy production. Vitamin $C$ is also involved in the synthesis of neurotransmitters, iron absorption and transport, reduced forms of intermediate folic acid. Vitamin $\mathrm{C}$ is also involved in the synthesis of collagen, which is approximately $1 / 3$ of the proteins of the body and is present in the skin and bones. Ascorbic acid deficiency and reduced collagen synthesis will lead to more frequent injuries. Vitamin $\mathrm{C}$ deficiency can also lead to fatigue and muscle weakness, and even anemia. Insufficient intake of vitamin $\mathrm{C}$ is also associated with weakening of the immune system. Due to the important role of vitamin $\mathrm{C}$ in the body, its deficiency may affect the player's performance and stamina during training (Naidu 2003; Lukaski 2004). Increased physical activity is a factor that increases the demand for this vitamin. The average content of vitamin $\mathrm{C}$ in the diets of the group of women studied was more than twice the norm, while in the diets of men was about half the norm. Moreover, a significant percentage of men did not fulfilled the dietary recommended value for vitamin C. Mullinix et al. (2003) obtained similar results in a group of physically active women who fulfilled DFR norm for vitamin $\mathrm{C}$ by $171 \%$. Other authors have received different results from their studies, which reported an abnormal concentration of vitamin $\mathrm{C}$ in the diet of women and men who participate in a variety of sports (Zapolska et al. 2014; Wierniuk and Włodarek 2013; Gogojewicz et al. 2012; Burke and Read 1988).

Vitamin $A$ is consumed in the diet as retinol from animal products or as pro-vitamin $A$ in the form of carotenoids from plant products. Thanks to its antioxidant properties, it neutralizes the effects of free radicals in the body and prevents DNA damage and oxidation of fatty acids. It is also responsible for ensuring the immunity of the body, especially the prevention of respiratory infections because it is involved in the processes of cell growth and 
differentiation of respiratory mucosa (Biesalski and Grimm 2012). People preparing for a marathon should therefore pay special attention to the adequate supply of this vitamin from the diet. Moderate activity can increase the body's immunity compared to people with sedentary lifestyles, but athletes who are involved in prolonged and intense exercise have more frequent infections of the upper respiratory tract compared with less active people (Moreira et al. 2009; Gleeson 2007). Immune function disorders occur most commonly in persons engaged in continuous, prolonged (approx. 1.5 hours) exercise of moderate to high intensity $\left(55-75 \% \mathrm{VO}_{2}\right.$ max). Another factor that may aggravate these disorders is the lack of food intake during prolonged exercises (Gleeson 2007).

Our study found that the vitamin $A$ in the diets of about $80 \%$ of women and $66 \%$ of men exceeded the EAR norm. Abnormal levels of vitamin A was also reported by other authors, assessing the diet of athletes in other disciplines (Chalcarz et al. 2008; Burke and Read 1988). The results of researches conducted in a number of groups of athletes, including endurance runners, however, showed normal dietary intake of vitamin A (Peters et al. 1993; Keith 1997; Lukaski 2004). To maintain a healthy supply of vitamin A in the diet of physically active people, attention should be paid to the type of food consumed. In physically active young women a decreased intake of vitamin A was noted, which was not related to a reduction in the supply of energy from the DFR. Probably, this decline was associated with a high intake of dietary fat and very low intake of fruit and vegetables (Johnson et al. 1972).

A significant part of the vitamin A in the diets of studied men and women was beta-carotene. In Hosegawa's (1993) studies, the effect of beta-carotene on the metabolism of sportsmen was investigated. Men were given a single dose of carotene two hours before training, while the control group received a placebo. The test results showed that the control group had significantly elevated levels of stress hormones. The elevated levels of these hormones were gradually reduced with an increasing dose of carotene and completely eliminated in men who received $30 \mathrm{mg}$ of carotene in a single dose. In a study conducted by Hyżyk and Romankow (2005) it was found that the DFR in the majority of physically active people are properly composed and included foods that are good sources of vitamins $\mathrm{C}$ and $\mathrm{E}$. A balanced nutritional ration for a whole day should cover the body's need for vitamins for physically active people as well, but for the people in these groups it is also popular to use dietary supplements. Research conducted by Frączek et al. (2012) showed that a vast majority of athletes (86.5\%) declared using dietary supplements. In addition, about $3 / 4$ of athletes declared that they take the vitamin and mineral preparations as antioxidant supplementation. Significantly more women than men enriched their diets with vitamin supplements.

A deficiency of certain vitamins can increase the time of recovery of protein and glycogen in the muscles and cause a decrease in mental and physical performance. Studies in a group of young rowers (Skarpańska-Stejnborn et al. 2001) showed that daily intake of antioxidant vitamins increases the antioxidant capacity of cells, increasing the body's protection against the effects of increased oxidative stress. Other authors have also demonstrated the role of antioxidants in preventing tissue damage after exertion (Sadowska-Krępa and Kłapcińska 2005). This was confirmed in studies by Poprzędzki (2003), in which supplementation with antioxidant vitamins and selenium resulted in improvement in exercise capacity, especially among endurance athletes. Athletes also declared using single vitamins, especially antioxidant in addition to multivitamins.

Athletes are exposed to chronic overexertion of the body during trainings and competitions, which may lead to a suppression of the immune system and increased oxidation of tissues and cells. Negative energy balance and insufficient supply of foods rich in antioxidants may also interfere with the immune system and antioxidant mechanisms. Moreover, the stress of exercise leads to a proportional increase in stress hormones and lowered immunity, including increased levels of pro-inflammatory cytokines. In addition to providing an appropriate 
amount of calories, during training exertion, the diet must also be enriched with antioxidant ingredients to resynthesize components of the immune system. Both shortages and excesses of these components may lead to immunosuppression. In some cases, supplementation with antioxidants may improve the immune system and replenish nutrients (Venkatraman and Pendergast 2002).

\section{Conclusions}

Most of the analyzed diets contained the correct amount of antioxidant vitamins. The average fulfilling of norms for vitamins $\mathrm{A}, \mathrm{C}$ and $\mathrm{E}$ significantly exceed the reference values established for the Polish population in the study group of men and women training for a marathon.

An insufficient supply of vitamin $C$ was found in the diets of approx. 1/3 of the men, which may indicate an inadequate intake of fruits and vegetables or their improper selection in this group of people.

Athletes engaging in regular, long-term exercise should pay attention to the correct balancing of daily food rations, since the deficit of nutrients, including antioxidant vitamins may cause a reduction in efficiency of the organism, and thus obtain a poorer performance during competitions.

\section{References}

Biesalski H.K., Grimm P. Żywienie. Atlas i podręcznik, ed. D. Gajewska. Elsevier Urban \& Partner, Wrocław 2012, 134-146, 154-156.

Bloomer R.J., Falvo M.J., Fry A.C., Schilling B.K., Smith W.A., Moore C.A. Oxidative stress response in trained men following repeated squats or sprints. Med Sci Sports Exerc. 2006; 38: 1436-1442.

Burke L.M., Read R. A study of dietary patterns of elite Australian football players. Can J Sports Sci. 1988; 13 (1): 15-19.

Chalcarz W., Merkiel S., Mikołajczyk A., Nowak E. Spożycie witamin i składników mineralnych w przeddzień meczu, w dzień meczu i po meczu. Bromat Chem Toksykol. 2008; 41: 681-685.

Czajka A. Wolne rodniki tlenowe a mechanizmy obronne organizmu. Now Lek. 2006; 75: 582-586.

Evans W.J. Vitamin E, vitamin C, and exercise. Am J Clin Nutr. 2000; 72 (suppl): 647-652.

Frączek B., Brzozowska E., Morawska M. Nutritional support of physical abilities in a professional athletes' group. Probl Hig Epidemiol. 2012; 93: 817-823.

Gacek M. Evaluation of consumption of selected nutrients in a group of hockey players during the preparation period. Roczn Panstw Zakl Hig. 2010; 61: 259-263.

Gleeson M. Immune function in sport and exercise. J Appl Physiol. 2007; 103: 693-699.

Gogojewicz A., Kasprzak Z., Pilaczyńska-Szcześniak Ł. Ocena sposobu odżywiania się kobiet aktywnych fizycznie w wieku 20-40 lat. Bromat Chem Toksykol. 2012; 45: 439-445.

Grajek W. Przeciwutleniacze w żywności. Aspekty zdrowotne, technologiczne, molekularne i analityczne. Wydawnictwa NaukowoTechniczne. Warszawa 2007.

Hosegawa T. Anti-stress effect of beta-carotene. Ann NY Acad Sci 1993, 691, 281.

Hyżyk A., Romankow J. Ocena stanu wysycenia organizmu witaminami antyoksydacyjnymi C i E oraz ich wpływ na wydolność fizyczną młodych sportowców. Rocz Panstw Zakł Hig. 2005; 56: 57-65.

Jarosz M. (ed). Normy żywienia dla populacji polskiej - nowelizacja. Instytut Żywności i Żywienia. Warszawa 2012, http://mail.izz.waw. pl/ it/NORMY/NormyZywieniaNowelizacjalZZ2012.pdf.

Johnson R.E., Mastropaolo J.A., Wharton M.A. Exercise, dietary intake and body composition. J Am Diet Assoc. 1972; 61: 399-403.

Keith R.E. Ascorbic acid. In: Sports nutrition: vitamins and trace elements, eds. I. Wolinsky, J.A. Driskell. Boca Raton, FL: CRC Press. 1997: 29.

Kunachowicz H., Nadolna I., Przygoda B., Iwanow K. Tabele składu i wartości odżywczej żywności. Wydawnictwo Lekarskie PZWL. Warszawa 2005. 
Lange E., Tymolewska-Niebuda B., Szydłowska-Krusiec J. Ocena sposobu żywienia mężczyzn uprawiających piłkę nożną. Med Sport. 2007; 23 (supl. 1): 34.

Lukaski H.C. Vitamin and mineral status: effects on physical performance. Nutrition. 2004; 20: 632-644.

Moreira A., Delgado L., Moreira P., Haahtela T. Does exercise increase the risk of upper respiratory tract infections? Br Med Bull. 2009; 90: 111-131.

Morillas-Ruiz J.M., Villegas Garcia J.A., López F.J., Vidal-Guevara M.L., Zafrilla P. Effects of polyphenolic antioxidants on exerciseinduced oxidative stress. Clin Nutr. 2006; 25: 444-453.

Mullinix M.C., Jonnalagadda S.S., Rosenbloom Ch.A., Thompson W.R., Kicklighter J.R. Dietary intake of female U.S. soccer players. Nutr Res 2003; 23: 585-593.

Naidu K.A. Vitamin C in human health and disease is still a mystery? An overview. Nutr J. 2003; 2: 7. DOI: 10.1186/1475-2891-2-7.

Nazar K. Fizjologia wysiłków fizycznych. In: Medycyna sportowa, eds. A. Jegier, K. Nazar, A. Dziak. Wydawnictwo Lekarskie PZWL, Warszawa 2013, 19-27.

Papadopoulou S.K., Papadopoulou S.D., Gallos G.K. Macro- and micro-nutrient intake of adolescent Greek female volleyball players. Int J Sport Nutr Excer Metab. 2002; 12: 73-80.

Peters E.M., Goetzsche J.M., Grobbelaar B., Noakes T.D. Vitamin C supplementation reduces the incidence of post race symptoms of upper-respiratory infection in ultramarathon runners. Am J Clin Nutr. 1993; 57: 170-174.

Pilis K., Michalski C., Zych M., Pilis A., Jelonek J., Kaczmarzyk A., Pilis W. A nutritional evaluation of dietary behaviour in various professional sports. Rocz Panstw Zakl Hig. 2014; 65: 227-234.

Poprzęcki S. Wpływ suplementacji witaminami antyoksydacyjnymi na zdolności wysiłkowe i system obrony antyoksydacyjnej młodych mężczyzn. Med Sport. 2003; 19: 207-216.

Radak Z., Taylor A.W., Ohno H., Goto S. Adaptation to exercise-induced oxidative stress: from muscle to brain. Exerc Immunol Rev. 2001; 7: 90-107.

Sachdev S., Davies K.J.A. Production, detection, and adaptive responses to free radicals in exercise. Free Radic Biol Med. 2008; 44: 215-223.

Sadowska-Krępa E., Kłapcińska B. Witaminy antyoksydacyjne w żywieniu sportowców. Med Sport. 2005; 21: $174-182$.

Sen C.K. Antioxidants in exercise nutrition. Sports Med. 2001; 31: 891-908.

Skarpańska-Stejnborn A., Szyszka K., Zembroń-Łacny A. Wpływ diety wzbogaconej w witaminy antyoksydacyjne na poziom glutationu i zawartość produktów peroksydacji lipidów we krwi wioślarzy. Med Sportiv. 2001; 5 (1): 35-40.

Szponar L., Wolnicka K., Rychlik E. Album fotografii produktów i potraw. Prace IŻŻ 96, Instytut Żywności i Żywienia, Warszawa 2008.

Valko M., Leibfritz D., Moncol J., Cronin M.T.D., Mazur M., Telser J. Free radicals and antioxidants in normal physiological functions and human disease. Int J Biochem Cell Biol. 2007; 39: 44-84.

Venkatraman J.T., Pendergast D.R. Effect of dietary intake on immune function in athletes. Sports Med. 2002; 32: 323-337.

Wierniuk A., Włodarek D. Estimation of energy and nutritional intake of young men practicing aerobic sports. Rocz Panstw Zakl Hig. 2013; 64: 143-148.

Zapolska J., Witczak K., Mańczuk A., Ostrowska L. Assessment of nutrition, supplementation and body composition parameters on the example of professional volleyball players. Rocz Państw Zakl Hig. 2014; 65: 235-242.

Cite this article aS:. Kosendiak A., Kawicka A., Dorota Różańska D., Konikowska K., Salomon A., Regulska-Ilow B. Dietary Intake of Antioxidant Vitamins in Diets of Amateur Adults Preparing For a Marathon. Central European Journal of Sport Sciences and Medicine. 2015; 11 (3): 71-79. 
